Ana Jovanović ${ }^{1}$

UDK: 371.3::81'243

University of Belgrade

https://doi.org/10.18485/imp.2017.ch.9

Faculty of Philology

\title{
LANGUAGE EDUCATION AND PHILOLOGICAL STUDIES: PERSPECTIVES FOR AN INTEGRATIVE APPROACH ${ }^{2}$
}

This paper represents a critical examination of contemporary L2 teaching methodologies and their role in the current development of philological studies. More precisely, we examine how task-based learning, CLIL, and collaborative language learning contribute to the general field of philology. With their focus on problem-solving activities and the integration of language and other content, as well as the importance they put on collaboration, these methods build on the central tenets of constructivism reflected in active engagement, cooperation, interdisciplinarity, and the development of critical thinking. It is suggested that these methods offer a useful venue for the integration of language and philological studies through their insistence on active participation in relevant communities of practice. In this way, they prepare students, professionalsin-development, for a proactive, responsible attitude and engagement in the selected professional field.

Keywords: collaborative learning, constructivism, educational linguistics, L2 learning, language teaching methodologies, philology.

\section{Introduction}

As a field of study, philology is not an easily defined concept. Quite the contrary, it provokes a lot of controversy since its utility, applicability,

1 anajovano@gmail.com

2 This study was completed as part of the project number 178014 Dynamics of the structures of modern Serbian language, financed by the Ministry of Education, Science and Technological Development of the Republic of Serbia. It grew out of a larger research project published in the monograph: Jovanović, Ana. Waking up from the university dream: intersection of educational ideologies and professional identity construction. Saarbrücken: Lambert Academic Publishing, 2016. 
and the very meaning of it vary considerably from discipline to discipline. It is traditionally brought into connection with areas that study the structure and development of language, linguistics, literary study, and interpretation (Ziolkowski 1990). Currently, however, philological studies seem to be undergoing a paradigm shift, very much like other spheres of humanities. Protagonists of present-day programs of philological studies (curriculum creators, teachers, administrative staff and other stakeholders) make a conscious effort to espouse philological tradition with a balanced approach to different disciplines that would provide a breadth of application, adaptability, capacity for life-long learning, and specific outcomes for the professionals in the field. This is mostly evident in a greater focus on "the importance of the contemporary, the local, and the interdisciplinary" (Salumets and Roche 1996: 7), which brings bold changes to the field of philology.

Here, we examine important contributions from the field of educational linguistics in order to evaluate to what extent they respond to these changing realities of philological studies. We open with a brief description of contemporary language teaching methodologies, so we can bring them together and examine them in relation to a holistic, applicable, engaged, and responsible philological education.

\section{Language teaching methods}

Educational linguistics and, by extension, foreign language education, grew as a discipline out of the need to refute "the simplistic notion that applied linguistics was simply linguistics applied to some practical questions" (Spolsky 2008: 1). It essentially represents a field relevant to education and based on linguistics that is intimately related with educational theories, linguistic theories, theories of second language acquisition, as well as language education policy, and general epistemological beliefs (Neuner \& Hunfeld 1993, as cited in Durbaba 2011: 92). As such, the evolution of educational linguistics has reflected the dynamics between different educational ideologies that have marked the evolution of humanities and social sciences. Thus, Richards and Rogers (2003) discuss theories of language and language learning that clearly align with positivist and constructivist ideologies. While in positivism learning is mainly perceived through acquisition, transmission of goods in the form of knowledge, con- 
structivism insists on the process of knowledge creation that must be completed through engagement in meaningful and purposeful activities (see Jovanović 2016). Although we might assume that this distinction has not always been made explicit throughout the history of the field, contemporary theories show great awareness of the debate between positivist and constructivist traditions and they have made it one of their important fields of reflection. Thus, early methods in language learning and teaching equated the language learning process with the acquisition of linguistic structures. It was assumed that an understanding and knowledge of different hierarchically organized units (phonemes, morphemes, syntagms, clauses, lexemes, etc.) could be qualified as knowledge of the language in question. This structuralist creed pervaded the field for more than a century and, due to the strong force of tradition, we must admit that it still lives on in many language classrooms.

However, with the advent of research related to communicative competence, much has changed in the perception of what language learning is. Thus, Hymes (1972) has differentiated between linguistic competence, that is, the knowledge of the linguistic system, and pragmatic competence, which enables a person to successfully use language in a specific socio-cultural context. The concept has lived through different interpretations (see Canale \& Swain 1980; Celce-Murcia, Dörnyei \& Thurrell, 1995; Council of Europe 2001), but the underlying idea has always been that of the complexity of language. The knowledge of a language is not equated with the knowledge of the linguistic system, as was the case with structuralism. Instead, it entails the capacity for correct and appropriate use of language in different contexts, which is developed through active participation in acts of communication. Thus, a language is not learned so it can be used but quite the opposite: a language needs to be used so it can be developed. In line with this idea, language essentially serves as a means of developing both linguistic knowledge and knowledge from other domains.

Contemporary methods in language education feed on this idea and develop it in different albeit related directions. Among the most influential methods that find their place in volumes on language teaching methodologies are task-based approach, content-based approach, and cooperative learning (e.g., Larsen-Freeman 1986/2000; Richards \& Renandya 2002; Richards \& Rogers 2003). These language teaching methods have 
also been well accepted and established in Spanish language education. Thus, the task-based approach has been particularly popular as a method for teaching Spanish as a foreign language, which is evident in an important number of books, papers, and edited volumes related to the topic (e.g., Zanón 1999; Fernández 2001; Estaire 2009, and others), as well as in a series of textbooks created in line with this conceptualization of language learning (particularly by the Spanish editorial Difusión). CLIL, in turn, has been especially fruitful in Spanish primary and secondary schools.

\subsection{Task-based approach}

Task-based learning aims to provide learners with a realistic context for language use by defining specific tasks that need to be solved. A task is any activity that may arise in real life and that implies language use (for instance, creation of a timetable, doing a survey and interpreting the results, filing a complaint, etc.). Ellis (2003) insists that all tasks obey six principles: 1 ) a task is a plan of activity; 2 ) the focus of a task is on meaning; 3 ) completion of a task requires the use of linguistic resources that are normally used in real-life situations; 4) a task implies the activation of any or all activities of communication (e.g. reception, production, and/or interaction in oral or written form); 5) a task activates cognitive processes such as selection, classification, reasoning, and evaluation of information, and 6) a task has well-established objectives and outcomes. In other words, the completion of a task requires an active engagement of the student on different levels: students need to understand the task so they can devise appropriate procedures for its completion. This process engages them on an intellectual level since they need to be able to look for relevant information, to organize it in a meaningful way, and to evaluate their learning process. A task entails realistic language use, which provides the necessary opportunities for participation in communicative situations. Finally, the completion of the task serves as immediate feedback to students: if the task is successfully completed, the students' engagement has also been successful. Estaire (2009) differentiates between communicative tasks and tasks of linguistic support to emphasize that the focus of this approach is on the balanced development of different aspects of communicative competence, that is, on linguistic, pragmatic, and sociolinguistic competences. 


\subsection{Content and language integrated learning (CLIL)}

CLIL combines the learning of language with the learning of other content, usually of academic nature. This helps students "to develop not only basic language competences but also cognitive academic language skills since the language used as an intermediate language in learning non-linguistic subjects is formal and contains abstract terms" (Zavišin 2013). Basically, CLIL does not imply a new methodology in learning languages or other contents; instead, it merges language education with the learning of some other content. Consequently, an approach that relies on CLIL has clearly stated objectives and outcomes in terms of both target language and content. As Larsen-Freeman (1986/2000) explains, the selection and sequence of language items arise from communicative needs and not so much from a predetermined syllabus.

As an alternative approach to language education, CLIL brings a number of advantages: 1 ) students are constantly exposed to the target language that must be comprehensible and harmonized with the content and students' needs; 2 ) the language is given in a meaningful context and not in isolated fragments so that students have ample opportunities to negotiate meanings; 3 ) the gradual introduction of more complex contents enables the students to rely on their previous knowledge; 4) tasks that are intrinsically interesting and cognitively engaging lead to better opportunities for language use; 5) the integration of language and content entails the application of a wide array of different learning strategies; 6) this approach opens space for a more flexible and adaptable curriculum, and 7) the educational process is student-centered because students have greater influence on the choice of topics and activities (Grabe \& Stoller 1997, as cited in Zavišin 2013: 30). CLIL bridges the boundaries between different disciplines and conceives of language as an instrument for understanding the content. Consequently, the objectives of this approach are formulated in terms of the development of communicative competence in the target language, but also in academic skills (Pica 2002). Finally, with its interdisciplinary approach, CLIL is very suitable for the development of intercultural communicative competence since it opens up opportunities for the exploration and interpretation of diverse cultural content that is inherently related to language (Vučo \& Zavišin 2011). 


\subsection{Collaborative language learning}

The main premise of cooperative or collaborative language learning refers to the interactive and collaborative nature of language learning. As Richards and Rogers (2003: 190-191) explain, this approach relies on five principles: 1) the main purpose of language is communication; 2) the most frequent communicative activity is conversation; 3) conversation operates on the basis of a number of determined rules or "collaborative maxims"; 4) people learn collaborative maxims by being socialized into the community, which occurs through participation in everyday situations, and 5) people learn collaborative maxims of the target language by participating in collaboratively structured activities of communication. These principles rely on the sociocultural theory of learning according to which knowledge has its roots in social and cultural context. Collaborative language learning is, additionally, frequently directed toward a solution of real problems students may have so that the goal of education may be to enable students to solve problems through collaborative efforts. In fact, teachers help students develop collaborative and social skills so that they can work together more effectively (Larsen-Freeman 1986/2000: 164).

The three approaches prioritize different aspects of the language learning process. Thus, the task-based approach is focused on problem-solving; CLIL relates language to naturalistic language use since language is a vehicle for learning other content; collaborative learning insists on the social nature of language where collaboration is central to the creation of new knowledge. Thus, these methods vary to a certain degree in the way language education is approached. However, they are not contradictory and they open up possibilities for their creative and effective integration. More importantly, they manifest certain common properties that align them with the constructivist ideology of education. They all aim at providing learners with an authentic context for language use by giving "priority to process over predetermined linguistic content" (Larsen-Freeman 1986/2000: 137). In other words, language learning occurs in contexts that are never divorced from meaning. Language is inseparable from meaning and is always situated in a specific context of communication. To know language, thus, means to know how to use it: knowledge is developed through use, through active participation in the activities of communication that enable the language learning process. 


\section{Theories of language learning}

Previously discussed approaches to language education spring from different theories of language learning: sociocultural theory, complexity theory, cognitive theory, identity approach to second language acquisition, language socialization approaches, to name only a few (Atkinson 2011).

Sociocultural theory has greatly influenced the field of educational linguistics (e.g. Lantolf 2000; Lantolf \& Poeher 2008; Johnson 2009; van Lier 2004). In this perspective, learning is always situated in physical and social contexts and influenced by persons, tools, and activities. Learners develop their knowledge by participating in relevant activities that allow them to appropriate a community's cultural artifacts through socialization. Central to this is the concept of the zone of proximal development (ZPD), that is, "the distance between the actual developmental level as determined by independent problem solving and the level of potential development as determined through problem solving under adult guidance or in collaboration with more capable peers" (Vygotsky 1978: 86). As conceived in the theory, learning does not follow development but, instead, it is a necessary condition for development. In fact, the only good learning is that which is in advance of development. The site where learning and development meet is known as the ZPD. However, "the ZPD is not a place or a context, but a dialectic unity of learning-and-development, or more appropriately, learning-leading-development" (Dunn \& Lantolf 1998: 420).

Moreover, a sociocultural perspective emphasizes the role of human agency in this developmental process:

How an individual learns something, what is learned, and how it is used will depend on the sum of the individual's prior experiences, the sociocultural contexts in which the learning takes place, and what the individual wants, needs, and/or is expected to do with that knowledge. (Johnson 2009: 2)

Evidently, learning is not limited to the individual, but rather related to and strongly influenced by the material and social environment in which the learning takes place. However, this environment is constantly changing, so in order to understand the learning process, contextual dynamics have to be considered as well. In other words, ontogenetic development 
may not be seen as an isolated trajectory, but as a process in relation to historical change on a number of other levels: a particular event in which an individual is involved; institutions such as the family, the school, and the workplace; the culture in which the individual and these institutions are embedded; and lastly, the human species as a whole (Wells 2000: 53-54).

Complexity theory shares with the sociocultural perspective the conviction in the inherent interconnectedness of the cognitive and the social (see Larsen-Freeman 1997; Larsen-Freeman 2011). However, it is also interested in how minds affect the social context: it supports "ecological accounts of learning that place its locus exclusively neither in the brain/body nor social interaction, but in their intersection" (Larsen-Freeman 2011: 66). This approach insists on understanding the relationships between the parts that connect them to the whole and it acknowledges the complex, open, adaptive, and dynamic nature of organized systems. These considerations have influenced research within the field of educational linguistics and have offered important practical implications for language teaching that do justice to the complexity of factors involved in the learning process. One of the main contributions has been a further elaboration of the idea that a language system is developed through use, in focused, meaningful, and engaging activities. Larsen-Freeman (2003), thus, talks of grammaring as a way to develop a linguistic system through its use and insists that the goal of language education is not to re-create in our classrooms the natural conditions of acquisition present in the external environment. Instead, what we want to do as language educators is "to improve upon natural acquisition, not emulate it. We do want our teaching to harmonize with our students' natural tendencies, but we want our teaching to accelerate the actual rate of acquisition beyond what students could achieve on their own" (Larsen-Freeman 2003: 20).

An authentic learning environment in which students are pushed to take an active role in the learning process is crucial for successful learning. Language use has a central place in this, as it has already been defended by Swain (1995). She has insisted on four functions of output, that is, enhancement of fluency through practice, promotion of gap/ problem noticing, learner hypothesis testing, and metalinguistic function. As we can see, three of these functions relate to the meta-knowing since they allow evaluation and consolidation of one's linguistic knowledge. Although language use serves the purpose of the development of 
one's linguistic system, it also implies the externalization of knowledge through collaboration with other members of the community. It entails a higher order of metacognitive awareness that is necessary for critical and creative thinking. Bruffee maintains that people learn judgment best in groups and that "the social process of learning judgment is a function of language and interpretation" (1999: 181). Learning does not imply the assimilation of knowledge, but people's assimilation into communities of knowledgeable peers. Bruffee further defends that learning is a sort of collective endeavor whose participants are connected by liaisons of interdependence. Education as a social activity is deeply moral since teachers need to help students "develop the ability to interact socially over complex, intellectually demanding issues, thus integrating social and intellectual maturity" (1999: 213). Conversation is here of highest importance for two interrelated reasons. Firstly, it enables the externalization of implicit, tacit knowledge, which is embedded in individual experiences (Nonaka and Takeuchi 1995: viii). As Paavola, Lipponen and Hakkarainen explain (2004: 559), the basic source of knowledge creation is tacit knowledge, which needs to be externalized and explicated. In this way, a new level of awareness is achieved since a person becomes able to reflect on his or her knowledge and to evaluate it. Secondly, the role of conversation is related to the crossing of boundaries. Namely, prior to the beginning of the educational process, the teacher and the student belong to different communities and they need to create common understanding, shared knowledge. Knowledge is not transmitted from the teacher to the student, nor is it the case that the student acquires the knowledge that is given to them. Instead, knowledge is created through communication between members of the newly created community in a way that allows participants to generate new meanings. Moreover, this process entails a reconsideration of one's affiliation. Thus, a freshman student feels allegiance to the communities he or she formed part of prior to entering university. Now, when introduced to the new context, the new discipline, the new community of practice, the student aspires to become its legitimate member, which affects his or her prior membership. Students' identity gets transformed and modified and teachers need to help them take an active part in this intellectual and emotional negotiation. 
The creation of shared knowledge or shared language occurs in quite an obvious manner in the case of foreign language education. The student enters a new community and develops the linguistic knowledge necessary to communicate with other members. However, the negotiation of meanings occurs constantly on a less obvious level at the intersection among all participants who bring their own cultures and knowledges to the educational process while striving to understand and interpret elements of the discipline and the target language culture. Geertz (1983/2000) discusses the possibility of mutual understanding in the multicultural context and insists on the inadequacy of the concept of empathy. We can never really imagine what it is that the other feels, knows, aspires to, since, by definition, we all come from different cultures. This is analogous to the myth of native-speaker fluency, which was set as the goal of language education for quite some time. Learners of the target language are not native speakers, so it is illusory that they might become something they could, by definition, never be. Similarly, we can never really fully empathize since our experiences are evidently different to those of the other. What we can try to reach is a mutual understanding through interpretation:

The problem of the integration of cultural life becomes one of making it possible for people inhabiting different worlds to have a genuine, and reciprocal, impact upon one another. If it is true that insofar as there is a general consciousness it consists of the interplay of a disorderly crowd of not wholly commensurable visions, then the vitality of that consciousness depends upon creating the conditions under which such interplay will occur. And for that, the first step is surely to accept the depth of differences; the second to understand what these differences are; and the third to construct some sort of vocabulary in which they can be publicly formulated. (Geertz 1983/2000: 161)

\section{Conclusion}

The implications of the previous discussion for language education, the study of language and culture in all its multitude of interconnected

fields are more than evident. Common to all these approaches is the goal-di- 
rected, real-life, authentic engagement, which enables students and teachers to create meanings within communities of practice. In order to help students mature and become responsible citizens of society, education needs to take on a new role. Scardamalia and Bereiter maintain that this means "changing the function of the school from that of service provider to that of a productive enterprise to which the students are contributors" (1999: 275). Here, the focus is not on cognitive processes alone or on the situatedness of cognition and social practices but rather on the progressive development of these practices and artifacts through mediated activities. In this model, knowledge creation is conceived by analogy with the work of a scientific research team. Similar to scientists who are trying to make sense of what their colleagues are up to so that they can work on new ideas on their own, students try to reconstruct information from textbooks and other relevant sources so that they can understand and contribute something. It is true that we are not to expect students to make a direct contribution to scientific theories, at least not in the initial stages of schooling. The idea is to prepare them to be able to engage in knowledge creation and to enable them to make sense of information about a topic of interest.

This is also in line with Larsen-Freeman's (2011) discussion on retrodiction. As opposed to the usual scientific procedure that aims to make predictions and test them, retrodiction looks for traces in the trajectory of a system. It explores what has already happened in order to give meaning to the observed phenomena and to understand changes in the system. "This is 'a trace' of the real system, from which we try to reconstruct the elements, interactions, and developmental processes of the system" (Byrne 2002, as cited in Larsen-Freeman 2011: 61). Naturally, we will have certain expectations about future occurrences, based on the prior experience and understandings of the system, but the focus is on explanation and interpretation, and not on prediction. Retrodiction in education would, then, imply a complete alteration of the traditional procedures that are usually introduced through clear segmentation between presentation-practice-production. Instead, students would look for traces in the relevant material in an attempt to reconstruct underlying theories, elements, and relationships within a concrete task. As Popper and Eccles (1977) explain, 
we can grasp a theory only by trying to reinvent it or to reconstruct it, and by trying out, with the help of our imagination, all the consequences of the theory that seem to us to be interesting and important. (Popper \& Eccles, 1977, as cited in Scardamalia \& Bereiter 1999: 279)

Consequently, the goal of philological education is to provide opportunities for students to reconstruct and recreate knowledge by exploring and interpreting relevant phenomena in meaningful contexts and situations. A crucial aspect of learning is, thus, meaning-making or creation of new knowledge and the evaluation of this new knowledge. In this way, the student assesses their relationships with the new knowledge in the present but also with respect to future projections and takes on the responsibility for their professional development. Furthermore, it allows the construction of our own knowledge through interactions with other people, places, tools, environments... Finally, it invites the crossing of disciplinary boundaries and the integration of linguistics, cultural studies, literary studies, interpretation, and other relevant fields.

What science, art, and education share within this paradigm is "intense seeing, the wide-eyed observing that generates empirical information" (Tufte 2006: 9; original emphasis). Art schools have traditionally emphasized this way of learning and teaching through the process called practice as research (see Nelson 2013). The design process, for instance, always implies innovation, but it also relies on the thorough research and good understanding of a problem in all of its intricacies. Only after defining a question or a problem and conducting a needs assessment together with an analysis of the market, can a design team proceed to the collaborative development of a new product. In this innovative stage, however, they mainly rely on abductive thinking - imaging what could be possible. This stage is, then, followed by an assessment of alternative ideas and hypotheses, that is, by critical thinking and evaluation with consequent revisions and improvements. This learning approach challenges assumed constraints; it stimulates the creation of new ideas instead of discouraging them. It revolves around the idea of knowledge creation and critical thinking. Importantly, this approach to learning does not diminish the importance of explicit knowledge; rather, it insists that, in addition to explicit knowledge, tacit knowledge should also be recognized in the educational 
process. Dialogue, discussion and active participation in the community of practice are crucial for the externalization of tacit knowledge, which, then, can be reconsidered, evaluated, and open to transformation in light of a new input. By this activity, students engage in critical thinking that enables them to reflect on their relationships with the self and the world. It opens ground for the reconsideration of their (professional) identity and prepares them for responsible participation in their community of practice, following the argument that "education that aims to promote critical thinking must stimulate students to participate in practices with the objective of improving the quality of society for everyone and to participate in the discussion on what exactly is 'quality'" (ten Dam \& Volman 2004: 373).

\section{REFERENCE LIST}

Atkinson, Dwight (ed.). Alternative approaches to second language acquisition. London/New York: Routledge, 2011. Print.

Bruffee, Kenneth A. Collaborative learning: Higher education. interdependence, and the authority of knowledge (2nd ed.). Baltimore, ML: The Johns Hopkins University Press, 1999. Print.

Canale, Michael \& Merrill Swain. "Theoretical bases of communicative approaches to second language teaching and testing." Applied Linguistics, Vol. 1, No. 1 (1980): 1-47. Print.

Celce-Murcia, Marianne, Zoltán Dörnyei \& Sarah Thurrell. "Communicative competence: A pedagogically motivated model with content specifications." Issues in Applied Linguistics, Vol. 6, No. 2 (1995): 5-35. Print.

Council of Europe. Common European framework of reference for languages: Learning, teaching, assessment. Cambridge, UK: Cambridge University Press, 2001. Print.

Dunn, William \& James Lantolf. “Vygotsky's zone of proximal development and Krashen's i + 1: Incommensurable constructs; Incommensurable theories." Language Learning, Vol. 48, No. 3 (1998): 411-442. Print.

Durbaba, Olivera. Teorija i praksa učenja i nastave stranih jezika. Beograd: Zavod za udžbenike, 2011. Print.

Ellis, Rod. Task-based language learning and teaching. Oxford: Oxford University Press, 2003. Print.

Estaire, Sheila. El aprendizaje de lenguas mediante tareas: de la programación al aula. Madrid: Edinumen, 2009. Print. 
Fernández, Sonsoles. (eds.) Tareas y proyectos en clase. Madrid: Edinumen, 2001. Print.

Geertz, Clifford. Local knowledge: Further essays in interpretive anthropology. New York: Basic Books, 1983/2000. Print.

Hymes, Dell H. "On communicative competence." John B. Pride \& Janet Holmes (eds.). Sociolinguistics. New York: Penguin, 1972. 269-293. Print.

Johnson, Karen E. Second language teacher education: A sociocultural perspective. New York: Routledge, 2009. Print.

Jovanović, Ana. Waking up from the university dream: intersection of educational ideologies and professional identity construction. Saarbrücken: Lambert Academic Publishing, 2016. Print.

Lantolf, James P. (ed.). Sociocultural theory and second language learning. Oxford: Oxford University Press, 2000. Print.

Lantolf, James P. \& Matthew E. Poehner (eds.). Sociocultural theory and the teaching of second languages. London: Equinox, 2008. Print.

Larsen-Freeman, Diane. "Chaos/complexity science and second language acquisition." Applied Linguistics, Vol. 18, No. 2 (1997): 141-165. Print.

Larsen-Freeman, Diane. Techniques and principles in language teaching. Oxford: Oxford University Press, 1986/2000. Print.

Larsen-Freeman, Diane. Teaching language: From gramar to grammaring. Boston, MA: Thomson Heinle, 2003. Print.

Larsen-Freeman, Diane. "A complexity theory approach to second language development/acquisition." Dwight Atkinson (ed.). Alternative approaches to second language acquisition. New York: Routledge, 2011. 48-72. Print.

Nelson, Robin (ed.). Practice as research in the arts: Principles, protocols, pedagogies, resistances. Hampshire: Palgrave Macmillan, 2013. Print.

Nonaka, Ikujiro \& Hirotaka Takeuchi. The knowledge-creating company: How Japanese companies create the dynamics of innovation. New York: Oxford University Press, 1995. Print.

Paavola, Sami, Lasse Lipponen \& Kai Hakkarainen. "Models of innovative knowledge communities and three metaphors of learning." Review of Educational Research, Vol. 74, No. 4 (2004): 557-576. Print.

Pica, Teresa. "Subject-matter content: How does it assist the interactional and linguistic needs of classroom language learners?" Modern Language Journal, Vol. 86, No. 1 (2002): 1-19. Print.

Richards, Jack C. \& Willy A. Renandya (eds.). Methodology in language teaching: An anthology of current practice. Cambridge: Cambridge University Press, 2002. Print. 
Richards, Jack C. \& Theodore S. Rogers. Enfoques y métodos en la enseñanza de lenguas. Madrid: Cambridge University Press, 2003. Print.

Salumets, Thomas \& Jörg Roche. "Germanics under construction: an introduction." Thomas Salumets \& Jörg Roche (eds.). Germanics under construction: Intercultural and interdisciplinary prospects. München: ludicium, 1996. 13-28. Print.

Scardamalia, Marlene \& Carl Bereiter. "Schools as knowledge-building organizations." Daniel P. Keating \& Clyde Hertzman (eds.). Today's children, tomorrow's society: The developmental health and wealth of nations. New York: Guilford, 1999. 274-289. Print.

Spolsky, Bernard. "Introduction: What is educational linguistics?" Bernard Spolsky \& Francis M. Hult (eds.). The handbook of educational linguistics. Oxford: Blackwell Publishing Ltd, 2008. 1-9. Print.

Swain, Merrill. "Three functions of output in second language learning." Guy Cook \& Barbara Seidlhofer (eds.). Principle and practice in applied linguistics: Studies in honor of H.G. Widdowson. Oxford: Oxford University Press, 1995. 125-144. Print.

Ten Dam, Geert \& Monique Volman. "Critical thinking as a citizenship competence: teaching strategies." Learning and Instruction, Vol. 14, No. 4 (2004): 359-379. Print.

Tufte, Edward R. Beautiful evidence. Cheshire, CT: Graphics Press LLC, 2006. Print.

Van Lier, Leo. The ecology and semiotics of language learning: A sociocultural perspective. Boston: Kluwer Academic Publishings, 2004. Print.

Vučo, Julijana \& Katarina Zavišin. "Bilingual education: the road to multilingualism." Azamat Akbarov (ed.). Foreign language teaching and applied linguistics. Sarajevo: International Burch University, 2011. 5-7. Web. 22.04.2016.

Vygotsky, Lav S. Mind in society: The development of higher psychological processes. Cambridge: Harvard University Press, 1978. Print.

Wells, Gordon. "Dialogic inquiry in education: Building on the legacy of Vygotsky." Carol D. Lee \& Peter Smagorinsky (eds.). Vygotskian perspectives on literacy research: Constructing meaning through collaborative inquiry. New York: Cambridge University Press, 2000. 51-85. Print.

Ziolkowsky, Jan. "What is Philology?: Introduction." Jan Ziolkowski (ed.). On philology. University Park, PA: The Pennsylvania State University Press, 1990. 1-12. Print.

Zanón, Javier (eds.). La enseñanza de E/LE mediante tareas. Madrid: Edinumen, 1999. Print. 
Zavišin, Katarina. Teorijske osnove i kritička analiza CLIL nastave na italijanskom i srpskom jeziku u srednjoj školi u Srbiji. Unpublished doctoral dissertation. University of Belgrade, 2013. Web. 15.03.2016.

\section{Ana Jovanović}

\section{ENSEÑANZA DE LENGUAS Y LOS ESTUDIOS FILOLÓGICOS: PERSPECTIVAS PARA UN ENFOQUE INTEGRATIVO}

\section{Resumen}

Este trabajo representa una revisión crítica de los métodos de la enseñanza de lenguas extranjeras contemporáneos y su papel en el desarrollo de los estudios filológicos. Exploramos, específicamente, las posibilidades para la contribución del enfoque por tareas, la enseñanza integrada de lengua y contenidos y la enseñanza colaborativa para el campo de filología. Estos métodos se fundan en las ideas fundamentales del constructivismo, especialmente reflejados en la participación activa, colaboración, interdisciplinaridad y desarrollo del pensamiento crítico, con énfasis en las actividades de solución de problemas, integración de aprendizaje de lengua con otros contenidos académicos y la importancia de la cooperación. Se sugiere que los métodos mencionados ofrezcan vías apropiadas para la integración de los estudios de lengua con otras disciplinas filológicas a través de la participación activa en las comunidades de práctica. De este modo, los estudiantes, profesionales-en-creación, se preparan para una actitud proactiva y responsable a la vez que una participación bien pensada en los diferentes campos profesionales.

Palabras clave: aprendizaje colaborativo, aprendizaje de LE, constructivismo, filología, lingüística educativa, métodos para la enseñanza de LE. 